Evi Purnamawati dan Hijawati, Freies Ermessen dalam Pemerintahan Indonesia, Halaman 98-109

\title{
FREIES ERMESSEN DALAM PEMERINTAHAN INDONESIA
}

\author{
Evi Purnamawati ${ }^{1}$ dan Hijawati ${ }^{2}$
}

${ }^{1}$ Fakultas Hukum Universitas Palembang

E-mail: evipurnamawatiplg@gmail.com

${ }^{2}$ Fakultas Hukum Universitas Palembang

E-mail : hijawati@unpal.ac.id

\begin{abstract}
Freies Ermessen is a freedom given to state administration in the context of administering government. So that Freies Ermessen is the freedom to act on its own initiative and policy from the state administration. In line with the increasing demands for public services that must be provided by State administration for the increasingly complex socio-economic life of citizens, however, the use of Freies Ermessen must not conflict with applicable law, both written law and unwritten law.
\end{abstract}

Keywords : Freies Ermessen; policy regulation

\begin{abstract}
Abstrak
Freies Ermessen adalah suatu kebebasan yang diberikan kepada tata usaha negara dalam melakukan penyelenggaraan pemerintahan. Sehingga Freies Ermessen merupakan kemerdekaan bertindak atas inisiatif dan kebijakan sendiri dari administrasi negara. Terjadinya suatu peningkatan akan adanya tuntutan pelayanan publik yang harus di berikan tata usaha negara terhadap kehidupan sosial ekonomi pada warga memiliki keberagaman, namun demikian penggunaan Freies Ermessen tidak boleh bertentangan dengan hukum yang berlaku baik hukum tertulis maupun hukum tidak tertulis.
\end{abstract}

Kata Kunci : Freies Ermessen; peraturan kebijakan

\section{PENDAHULUAN}

Suatu peraturan kebijakan senantiasa tidak dapat dilepaskan dengan kewenangan bebas (vrije Bevoegdheid) dari pemerintah dengan istilah Freies Ermessen. Freies Ermessen memiliki makna bahwa orang yang memiliki kebebasan untuk menilai, menduga dan mempertimbangkan sesuatu. Istilah tersebut sering digunakan dalam bidang pemerintahan, sehingga freies Ermeseen (diskresionare power) diartikan sebagai salah satu sarana yang memberikan ruang bergerak bagi pejabat atau bidang-bidang administrasi negara untuk melakukan tindakan tanpa harus terikat sepenuhnya pada undang-undang. Nana Saputra memberikan definisi tersebut suatu kebebasan yang diberikan kepada alat administrasi, yaitu kebebasan yang pada asasnya memperkenakan alat administrasi Negara mengutamakan keefektifan tercapainya suatu tujuan

1 Marcus Lukman, "Eksistensi Peraturan Kebijaksanaan dalam Bidang Perencanaan dan Pelaksanaan Recana Pembangunan di Daerah Serta Dampaknya terhadap pembangunan Materi Hukum Tertulis Nasional," Disertasi, (Bandung: Universitas Padjajaran, 1996). 
Evi Purnamawati dan Hijawati, Freies Ermessen dalam Pemerintahan Indonesia, Halaman 98-109

(doelmatigheid) dari pada berpegang teguh kepada kententuan hukum, atau kewenangan yang sah untuk turut campur dalam kegiatan sosial guna melaksanakan tugas-tugas menyelenggarakan kepentingan umum. $^{2}$

Pendapat lain dari Bachsan Mustafa yang menyatakan bahwa Freies Ermessen diberikan kepada pemerintah mengingat fungsi pemerintah atau administrasi negara yaitu menyelenggarakan kesejahteraan umum yang berbeda dengan fungsi kehakiman untuk menyelesaikan sengketa antar penduduk. ${ }^{3}$ Keputusan pemerintah lebih mengutamakan pencapaian tujuan atau sasarannya (doelmatigheid) daripada sesuai dengan hukum yang berlaku (rechtmatigheid). ${ }^{4}$

$$
\text { Meskipun pemberi Freies }
$$

Ermessen kepada pemerintah atau administasi Negara merupakan konsekuensi logis dari konsepsi welfare state, akan tetapi dalam kerangka negara hukum, freies ermenssen ini tidak dapat digunakan

\footnotetext{
${ }^{2}$ Marbun, S.F, Hukum Administrasi Negara I (Yogyakarta: UII Press, 2012).

3 I Nyoman Mangku Suryana, "Pembatasan Terhadap Asas Freies Ermessen," SINTESA: Jurnal Ilmu Sosial dan Ilmu Politik, Volume 9, Nomor 2, September 2018.

4 "Diskresi (Freies Ermessen)," http://ejournal.ipdn.ac.id/khatulistiwa/article/do wnload/922/587.
}

tanpa batas. Atas dasar itu, Sjachran Basah mengemukakan unsur-unsur Freies Ermessen dalam suatu Negara hukum yaitu:

a. Ditujukan untuk menjalankan tugas - tugas servis publik;

b. Merupakan sikap tindak yang aktif dari administrasi Negara;

c. Sikap tindak itu dimungkinkan oleh hukum

d. Sikap tindak itu diambil atas inisiatif sendiri;

e. Sikap tindak itu dimaksudkan untuk menyelesaikan persoalanpersoalan penting yang timbul secara tiba-tiba.

f. Sikap tindak itu dapat dipertanggungjawabkan baik secara moral kepada Tuhan yang Maha Esa maupun secara hukum. $^{5}$

Kewenangan pada Freies Ermessen atau diskresi, sebagai salah satu keputusan administrasi, kepada penyelenggaran pemerintahan. Pejabat pemerintahan yang berdasarkan diskresi diharapkan menjadi pintu masuk bagi terwujudnya kesejahteraan masyarakat, mengingat proses penyelesaian masalah masyarkat bisa menjadi lebih cepat.

Permasalahan untuk menganalisis implementasi kebijakan Freies

\footnotetext{
5 Sengketa Administrasi dalam Buku Bunga Rampai Hukum Tata Nagera dan Hukum Administrasi Negara, (Yogyakarta : Jurusan HTN, Fakultas Hukum UII, 1987).
} 
Evi Purnamawati dan Hijawati, Freies Ermessen dalam Pemerintahan Indonesia, Halaman 98-109

Ermessen oleh pejabat pemerintahan berdasarkan peraturan perundangan yang berlaku dengan memberikan pemahaman agar tidak terjadi tindakan sewenang-wenang atas diberikannya Freies Ermessen tersebut.

\section{PEMBAHASAN}

\section{A. Peraturan Kebijakan}

Didalam penyelenggaraan tugas tugas administrasi Negara pemerintah banyak mengeluarkan kebijakan yang dituangkan dalam berbagai bentuk seperti beleidslijnen (garis - garis kebijakan), het beleid (kebijakan), voorschriften (peraturan-peraturan), richtlijnen (pedoman-pedoman), regelingen (petunjuk-petunjuk), circulaires (surat edaran), resoluties (nota kebijakan), reglemen ministriele (peraturan-peraturan menteri), beschikkingen (keputusan-keputusan), enbekenmakingen (pengumumanpengumuman). ${ }^{6}$ Menurut Philipus $\mathrm{M}$. Hadjon, peraturan kebijakan pada hakikatnya merupakan produk dari perbuatan tata usaha Negara yang bertujuan "naar buiten gebracht schricftelijk beleid". Yaitu menampakkan keluar suatu kebijakan

${ }^{6}$ J.H Van Kreveld, Beleidsregel in het Recht, Kluwer - Deventer, 1983. tertulis. ${ }^{7}$ Peraturan kebijakan hanya berfungsi sebagai bagian dari operasional penyelenggaraan tugas tugas pemerintahan, karenanya tidak dapat mengubah ataupun menyimpangi peraturan perundang - undangan. Peraturan ini adalah semacam hukum bayangan dari undang - undang atau hukum. Oleh Karena itu, peraturan ini disebut pula dengan istilah psudo wetgeving (perundang - undangan semu) atau spigelsrecht (hukum bayangan / cermin).

Secara praktis kewenangan diskresioner administrasi Negara yang kemudian melahirkan peraturan kebijakan, mengandung dua aspek pokok; Pertama, kebebasan menafsirkan mengenai ruang lingkup wewenang yang dirumuskan dalam peraturan dasar wewenangnya. Aspek pertama ini lazim dikenal dengan kebebasan menilai yang bersifat objektif. Kedua, kebebasan untuk menentukan sendiri dengan cara bagaimana dan kapan wewenang yang dimiliki administrasi Negara itu dilaksanakan. Aspek kedua ini dikenal dengan kebebasan menilai yang

\footnotetext{
${ }^{7}$ Philipus M. Hadjon, et.al, Pengantar Hukum Administrasi Indonesia. Introduction to the Indonesian Administrative Law (Yogyakarta: Gadjah Mada University Press, 2011).
} 
Evi Purnamawati dan Hijawati, Freies Ermessen dalam Pemerintahan Indonesia, Halaman 98-109

bersifat subjektif. ${ }^{8}$ Kewenangan bebas untuk menafsirkan secara mandiri dari pemerintah inilah yang melahirkan peraturan kebijakan.

\section{Ciri-Ciri Peraturan Kebijakan}

Bagir Manan menyebutkan ciri-ciri peraturan kebijakan sebagai berikut :

1) Peraturan kebijakan bukan merupakan peraturan perundang-undangan.

2) Asa-asa pembatasan dan pengujian terhadap peraturan perundang-undangan tidak dapat diberlakukan pada peraturan kebijakan.

3) Peraturan kebijakan tidak dapat diuji secara wetmatigheid, karena memang tidak ada dasar peraturan perundang-undangan untuk membuat keputusan peraturan kebijakan tersebut.

4) Peraturan kebijakan dibuat berdasarkan bersangkutan membuat peraturan perundangundangan.

5) Pengujian terhadap peraturan kebijakan lebih diserahkan pada doelmatigheid dank arena itu

${ }^{8}$ Indroharto, Perbuatan Pemerintah Menurut Hukum Publik dan Hukum Perdata, Bahan Kuliah pada Program Pendidikan lanjutan Ilmu Hukum Bidang Peradilan Tata Usaha Negara, (Jakarta : Universitas Indonesia, 1992). batu ujinya adalah asas - asas umum pemerintahan yang baik.

6) Dalam praktik diberi format dalam berbagai bentuk dan jenis aturan, yakni keputusan, instruksi, surat edaran, pengumuman dan lain - lain, bahkan dijumpai dalam bentuk peraturan. ${ }^{9}$

\section{Fungsi dan Penormaan}

\section{Peraturan Kebijakan}

Penyelenggaraan urusan pemerintahan dalam suatu negara hukum itu bersendikan pada peraturan perundang-undangan sesuai dengan prinsip yang dianut dalam suatu Negara hukum yaitu asa legalitas, akan tetapi karena peraturan perundang-undangan sebagai hukum tertulis itu mengandung kekurangan dan kelemahan, sebagaimana telah disebutkan di atas, karena itu keberadaan peraturan kebijakan menempati posisi penting terutama dalam negara hukum modern. Menurut Marcus Lukman, peraturan kebijakan dapat di fungsikan secara tepat guna dan berdaya guna sebagai berikut.

1) Tepat guna dan berdayaguna sebagai sarana pengaturan yang

\footnotetext{
${ }^{9}$ Bagir Manan, Makalah, Jakarta, 1994.
} 
Evi Purnamawati dan Hijawati, Freies Ermessen dalam Pemerintahan Indonesia, Halaman 98-109

melengkapi, menyempurnakan, harus memerhatikan beberapa dan mengisi kekuranganpersyaratan. Menurut Indroharto, kekurangan yang ada pada peraturan perundang-undangan;

2) Tepat guna dan berdayaguna sebagai sarana pengaturan bagi keadaan vacuum peraturan perundangan-undangan;

3) Tepat guna dan berdayaguna sebagai sarana pengaturan bagi kepentingan-kepentingan yang belum terakomodasi secara patut, layak, benar dan adil dalam peraturan perundangan - undangan;

4) Tepat guna dan berdayaguna sebagai sarana pengaturan untuk mengatasi kondisi peraturan perundang - undangan yang sudah ketinggalan zaman;

5) Tepat guna dan berdayaguna bagi kelancaran pelaksanaan tugas dan fungsi administrasi di bidang pemerintahan dan pembangunan yang bersifat cepat berubah atau memerlukan pembaharuan sesuai dengan situasi dan kondisi yang dihadapi.

Sebagaimana pembuatan dan penerapan peraturan perundangundangan, yaitu harus memerhatikan beberapa persyaratan, pembuatan dan penerapan peraturan kebijakan juga pembuatan peraturan kebijakan harus memerhatikan hal-hal sebagai berikut: ${ }^{10}$

1) Ia tidak boleh bertentangan dengan peraturan dasar yang mengandung wewengan diskresioner yang dijabarkan itu;

2) Ia tidak boleh nyata-nyata bertentangan dengan nalar yang sehat;

3) Ia harus dipersiapkan dengan cermat; semua kepentingan, keadaan-keadaan serta alternatif alternatif yang ada perlu dipertimbangakan;

4) Isi dari kebijakan harus memberikan kejelasan yang cukup mengenai hak - hak dan kewajiban dari warga yang terkena peraturan tersebut;

5) Tujuan-tujuan dan dasar-dasar pertimbangan mengenai kebijakan yang akan ditempuh harus jelas;

6) Ia harus memenuhi syarat kepastian hukum materiil, artinya hak-hak yang telah diperoleh dari warga masyarat yang terkena harus dihormati, kemudian juga harapanharapan warga yang pantas telah

${ }^{10}$ Indroharto, Perbuatan Pemerintah 
Evi Purnamawati dan Hijawati, Freies Ermessen dalam Pemerintahan Indonesia, Halaman 98-109

ditimbulkan jangan sampai

diingkari.

Sedangkan dalam penerapan atau penggunaan peraturan kebijakan harus memerhatikan hal - hal sebagai berikut:

1) Harus sesuai dan serasi dengan tujuan undang undangan yang memberikan beoordelingsvrijheid (ruang kebebasan bertindak);

2) Serasi dengan asas - asas hukum umum yang berlaku, seperti :

3) Asas perlakukan yang sama menurut hukum;

4) Asas kepatutan dan kewajaran;

5) Asas keseimbangan;

6) Asas pemenuhan kebutuhan dan harapan; dan

7) Asas kelayakan mempertimbangkan segala sesuatu yang relevan dengan kepentingan public dan warga masyarakat.

8) Serasi dan tepat guna dengan tujuan yang hendak dicapai. ${ }^{11}$

Peraturan kebijakan sesuai dengan kemunculannya yakni bukan berasal dari kewenangan pembuatan peraturan perundang-undangan

${ }^{11}$ Marcus Lukman dalam Mohammad Yuhdi, "Peran Diskresi dalam Penyelenggaraan Pemerintahan," LIKHITAPRAJNA Jurnal Ilmiah, Volume 15 No. 1. (wetgevende bevoegdheid), karena itu tidak dapat diuji dengan mendasarkan pada aspek rechtmatigheid. Berdasarkan Hukum Administrasi Negara, pengujian peraturan kebijakan adalah aspek doelmatigheid dengan menggunakan asas - asas umum pemerintahan yang baik (AAUPB), khususnya asas larangan penyalahgunaan wewenang (detournement de pouvoir) dan asas larangan sewenang _ $\quad$ wenang (willekeur). Dengan kata lain, kebijakan pemerintah akan dikategorikan sebagai kebijakan yang menyimpang jika di dalamnya ada unsur penyalahgunaan wewenang dan unsur sewenang - wenang.

Ada tidaknya unsur penyalahgunaan wewenang diuji dengan asas spesialitas (specialiteitsbeginsel). Asas spesialitas ini mengandung arti bahwa wewenang itu diberikan kepada organ pemerintahan dengan tujuan tertentu. ${ }^{12}$ Menyimpang dari tujuan diberikannya wewenang akan dianggap sebagai penyalahgunaan wewenang. Adapun unsur sewenang-wenang diuji dengan asas rasionalitas atau kepantasan

12 L.J.A. Damen, et.al., Bestuusrecht, System, Bevoegdheid, Bevoegdheidsuitoefening, Handhaving (Den Haag: BJU Boom Juridische Uitgebers, Tweede Druk, 2005). 
Evi Purnamawati dan Hijawati, Freies Ermessen dalam Pemerintahan Indonesia, Halaman 98-109

(redelijk). Suatu peraturan kebijakan dikategorikan mengandung usnur willekeur jika peraturan kebijakan itu nyata-nyata tidak masuk akal atau tidak beralasan (kennelijk onredelijk).

Batasan sebagaimana diuraikan diatas merupakan wujud dari konsep dasar Negara hukum yang melandasi welfare state, artinya sekalipun dalam konsep welfare state dimungkinkan banyaknya campur tangan pemerintah terhadap urusan masyarakat, namun sebagai Negara hukum tetap harus patuh terhadap kerangka dasar yaitu dengan tetap memperhatikan peraturan perundangan yang berlaku, sehingga tindakan tidak menjadi liar dan merugikan masyarakat. Sebab jika hal tersebut yang terjadi, maka jelas Freies Ermessen yang dimaksudkan untuk mensejahterakan masyarakat dengan misalnya penyelesaian secara cepat.

"Perilaku atau perbuatan melawan hukum, melampaui wewenang, menggunakan wewenang untuk tujuan lain dari yang menjadi tujuan wewenang tersebut, termasuk kelalaian atau pengabaian kewajiban hukum dalam penyelenggaraan pelayanan publik yang dilakukan oleh Penyelenggara Negara dan pemerintahan yang menimbulkan kerugian materiil dan/atau immaterial bagi masyarakat dan orang perseorangan."

Maladministrasi yang dilakukan oleh pejabat sangat merugikan bagi warga masyarakat,${ }^{13}$ untuk itulah dalam rangka menuju good governance, pemerintah Indonesia telah mengesahkan Undang-undang Nomor 37 Tahun 2008 tentang Ombudsman Republik Indonesia. Melalui Undang Undang tersebut maka lahirlah lembaga pengawasan yang khusus di bidang pelayanan publik yaitu berkait maladministrasi. Pasal 2 Undang Undang Nomor 37 Tahun 2008 tentang Ombudsman Republik Indonesia menyatakan, bahwa:

"Ombudsman merupakan lembaga negara yang bersifat mandiri dan tidak memiliki hubungan organik dengan lembaga negara dan instansi pemerintahan lainnya, serta dalam menjalankan tugas dan wewenangnya bebas dari campur tangan kekuasaan lainnya."

Freies Ermessen dalam pelaksanaanya sangat dimungkinkan untuk terjadinya maladministrasi jika

13 Soviah Hasanah, "Bentuk-Bentuk Maladministrasi,"

https://www.hukumonline.com/klinik/a/bentuk -bentuk-maladministrasi-lt58292617134da 
Evi Purnamawati dan Hijawati, Freies Ermessen dalam Pemerintahan Indonesia, Halaman 98-109

hal tersebut tidak dikawal dengan rambu-rambu pembatas, sekalipun kelahiran Freies Ermessen itu sendiri adalah dalam rangka untuk untuk melengkapi asas legalitas dalam konsep negara hukum. Adalah hal yang sangat ironis, jika dengan Freies Ermessen yang dimaksudkan untuk menyelesaikan masalah yang dihadapi warga masyarakat menuju kepada kesejahteraan justru menimbulkan masalah baru berupa kerugian akibat tindakan sewenang-wenang dengan mendasarkan pada pemikiran makna "kebebasan" yang diberikan oleh Freies Ermessen tersebut. ${ }^{14}$

\section{Pendayagunaan Freies Ermessen} Pejabat Pemerintahan di

\section{Indonesia}

Tujuan untuk mensejahterakan masyarakat melalui Freies Ermessen yang melekat pada sebuah jabatan, dan akhirnya jabatan tersebut akan diemban oleh seorang pejabat, maka dalam pelaksanaannya tetap harus mendasarkan pada adanya pertanggungjawaban atas Freies Ermessen tersebut. Untuk itu, maka

$\begin{array}{lllr}14 \quad \text { Dyah Adriantini } & \text { Sintha } & \text { Dewi, } \\ \text { "Pendayagunaan Freies } & \text { Ermessen } & \text { Pejabat } \\ \text { Pemerintah dalam } & \text { Konsep } & \text { Negara } \\ \text { Kesejahteraan," Yustisia } & \text { Vol. 5 Januari - April } \\ \text { 2016. }\end{array}$

khusus tentang masalah freies ermessen, di mana Undang-Undang Nomor 30 Tahun 2014 tentang Administrasi Pemerintahan menyebut dengan istilah "diskresi" telah mengatur hal tersebut yaitu dalam $\mathrm{BAB}$ IV. Dalam Pasal 22 Undang-Undang Nomor 30 Tahun 2014 tentang Administrasi Pemerintahan, disebutkan bahwa diskresi hanya dapat dilakukan oleh Pejabat Pemerintahan yang berwenang dengan tujuan untuk:

a. Melancarkan penyelenggaraan pemerintahan.

b. Mengisi kekosongan hukum.

c. Memberikan kepastian hukum.

d. Mengatasi stagnasi pemerintahan dalam keadaan tertentu guna kemanfaatan dan kepentingan umum.

Selanjutnya, Pasal 23 UndangUndang Nomor 30 Tahun 2014 tentang Administrasi Pemerintahan menjelaskan bahwa ruang lingkup diskresi adalah:

a. Pengambilan Keputusan dan/ atau Tindakan berdasarkan ketentuan peraturan perundangundangan yang memberikan suatu pilihan Keputusan dan/ atau Tindakan. 
Evi Purnamawati dan Hijawati, Freies Ermessen dalam Pemerintahan Indonesia, Halaman 98-109

b. Pengambilan Keputusan dan/ atau Tindakan karena peraturan perundang-undangan tidak mengatur.

c. Pengambilan Keputusan dan/atau Tindakan karena peraturan perundang-undangan tidak lengkap atau tidak jelas; dan

d. Pengambilan Keputusan dan/ atau Tindakan karena adanya stagnasi pemerintahan guna kepentingan yang lebih luas.

Dengan demikian jelas bahwa sekali Freies Ermessen atau diskresi diperbolehkan, namun hal tersebut adalah dalam kondisi yang telah ditentukan. Sebagai contoh, misalnya jika dalam suatu wilayah terjadi adanya bencana alam, wabah penyakit, maupun konflik sosial maka sangat dimungkinkan untuk dipergunakan freies ermessen.

Hal lain yang wajib diperhatikan dalam pendayagunaan Freies Ermessen bagi para pejabat, adalah pemahaman berkait dengan akibat hukum. Bahwa sebagaimana diuraikan di atas, bahwa sangalah mungkin Freies Ermessen itu termasuk dalam tindakan melampaui wewenang atau mencampuradukkan wewenang yang dapat berakibat bahwa Freies Ermessen tersebut menjadi tidak sah atau dapat dibatalkan. ${ }^{15}$

Adapun yang dikategorikan melampaui wewenang sebagaimana diatur dalam Pasal Undang-Undang Nomor 30 Tahun 2014 tentang Administrasi Pemerintahan adalah jika Freies Ermessen atau diskresi itu dilakukan dengan melampaui batas waktu dan batas wilayah berlakunya wewenang yang diberikan oleh ketentuan peraturan perundangundangan, dan hal ini menimbulkan akibat hukum bahwa hal tersebut adalah tidak sah.

Sementara Pasal 31 UndangUndang Nomor 30 Tahun 2014 tentang Administrasi Pemerintahan menguraikan bahwa penggunaan Freies Ermessen atau diskresi termasuk dalam kategori mencampur adukkan wewenang jika tidak sesuai dengan tujuan wewenang yang diberikan dan bertentangan dengan dengan Asas-asas Umum Pemerintahan yang Baik (AUPB).

Berkait dengan Asas-asas Umum Pemerintahan yang Baik

15 Dyah Adriantini Sintha Dewi, "Pendayagunaan Freies Ermessen Pejabat Pemerintah dalam Konsep Negara Kesejahteraan." 
Evi Purnamawati dan Hijawati, Freies Ermessen dalam Pemerintahan Indonesia, Halaman 98-109

(AUPB) sebagai salah satu filter freies ermessen, keberadaannya menjadi hal sangat diperlukan, supaya Freies Ermessen tersebut tidak sia-sia tapi justru bermanfaat bagi masyarakat luas sesuai maksud diberikannya kewenangan tersebut. Sebagai wujud keseriusan pemerintah dalam upaya memberikan layanan yang terbaik bagi masyarakat, mengingat bahwa pada dasarnya pejabat adalah pelayanan masyarakat yang wajib memberikan pelayanan publik yang baik. Mengingat bahwa, yang dimaksud pelayanan publik meliputi hal yang sangat luas, sebagaimana diuraikan dalam Pasal 1 ayat (1) UndangUndang Nomor 25 Tahun 2009 tentang Pelayanan Publik, bahwa :

"Pelayanan publik adalah kegiatan atau rangkaian kegiatan dalam rangka pemenuhan $\mathrm{k}$ ebutuhan pelayanan sesuai dengan peraturan perundang-undangan bagi setiap warga negara dan penduduk atas barang, jasa, dan/ atau pelayanan administratif yang disediakan oleh penyelenggara pelayanan publik."

a. Peraturan kebijakan bukan merupakan peraturan perundang-undangan. b. Asas-asas pembatasan dan pengujian terhadap peraturan perundangan tidak dapat diberlakukan pada peraturan kebijaksanaan.

c. Peraturan kebijaksanaan tidak dapat diuji secara wetmatigheid.

d. Peraturan kebijaksanaan dibuat berdasarkan Freies Ermessen dan ketiadaan wewenang administrasi negara tersebut untuk membuat peraturan perundangan.

e. Batu ujinya adalah AUPB.

f. Bentuknya dapat berupa keputusan, instruksi, surat edaran, pegumuman, peraturan.

Berdasarkan uraian di atas, pendayagunaan Freies Ermessen pejabat pemerintahan perlu dibarengi dengan keberadaan sarana kontrol, yang dapat meliputi kontrol yudisial, kontrol politik, kontrol administratif.

Dalam kontrol yudisial, sekalipun pengujian Freies Ermessen mendasarkan pada doelmatigheid, yang mana pengadilan tidak berwenang dalam hal ini, namun jika freiesermessen tersebut mengandung 
Evi Purnamawati dan Hijawati, Freies Ermessen dalam Pemerintahan Indonesia, Halaman 98-109

unsur penyalahgunaan wewenang atau sewenang-wenang, maka pengadilan dapat masuk dalam permasalahan ini, kecuali hal tersebut berkait dengan isu efisiensi dan efektivitas.

Kontrol politik yang dimaksud di sini adalah kontrol yang dilakukan oleh DPR sesuai dengan Pasal 20A Ayat (1) Undang-Undang Dasar Negara Republik Indonesia Tahun 1945, bahwa "Dewan Perwakilan Rakyat memiliki fungsi legislasi, fungsi anggaran, dan fungsi pengawasan." Adapun output dari kontrol politik adalah perbaikan kebijakan di masa depan.

Sementara itu, dalam kontrol administratif, di Indonesia dikenal adanya upaya administratif sebagaimaa diatur dalam Pasal 48 UndangUndang Nomor 5 Tahun 1986 tentang Peradilan Tata Usaha Negara, yang meliputi keberatan dan banding administratif.

\section{KESIMPULAN DAN \\ REKOMENDASI}

Freies Ermessen merupakan kemerdekaan bertindak atas inisiatif dan kebijakan sendiri dari administrasi Negara. Freies Ermessen merupakan suatu bentuk penyimpangan terhadap asas legalitas dalam pengertian wet matiaheid van bestuur. Perwujudan sikap tindak dari administrasi Negara dalam implementasi Freies Ermessen bisa terdiri dari beberapa hal diantaranya membentuk peraturan perundang-undangan di bawah undangundang yang secara materiil mengikat umum. Selain itu juga mengeluarkan beschikking yang bersifat konkrit, final dan individual, serta menjalankan tindak administrasi yang nyata aktif dan menjalankan fungsi quasi, yudisial, terutama "keberatan" dan "banding administrasi”.

Freies Ermessen (diskresi) merupakan asas yang diberikan kepada pelaksana Negara untuk mengambil tindakan sesuai dengan pendapat sendiri dalam keadaan mendesak demi kemaslahatan bersama. Freies Ermessen oleh pejabat pemerintahan dalam rangka usaha untuk memujudkan kesejahteraan masyarakat sesuai dengan tujuan negara tercapainya masyarakat yang adil, makmur dan sejahtera, dalam pelaksanaannya harus mendapat pengawalan baik dari unsur - unsur yang membatasi Freies Ermessen itu sendiri, maupun penerapan AUPB sebagai pendamping. Di samping itu, 
Evi Purnamawati dan Hijawati, Freies Ermessen dalam Pemerintahan Indonesia, Halaman 98-109

keberadan lembaga kontrol juga sangat dibutuhkan supaya tidak terjadi tindakan penyalahgunan wewenang maupun tidakan yang sewenangwenang, yang mana hal tersebut merupakan awal dari terjadinya maladministrasi.

\section{DAFTAR PUSTAKA}

Bagir Manan, Makalah, Jakarta, 1994.

Dyah Adriantini Sintha Dewi, "Pendayagunaan Freies Ermessen Pejabat Pemerintah dalam Konsep Negara Kesejahteraan," Yustisia Vol. 5 Januari - April 2016.

Indroharto, Perbuatan Pemerintah "Diskresi (Freies Ermessen)," http://ejournal.ipdn.ac.id/khatuli stiwa/article/download/922/587.

I Nyoman Mangku Suryana, "Pembatasan Terhadap Asas Freies Ermessen," SINTESA: Jurnal Ilmu Sosial dan Ilmu Politik,

Volume 9, Nomor 2, September 2018.

J.H Van Kreveld, Beleidsregel in het Recht, Kluwer - Deventer, 1983.

L.J.A. Damen, et.al., Bestuusrecht, System, Bevoegdheid,

Bevoegdheidsuitoefening,

Handhaving, Den Haag: BJU Boom Juridische Uitgebers, Tweede Druk, 2005.

Marcus Lukman, "Eksistensi Peraturan Kebijaksanaan dalam Bidang Perencanaan dan Pelaksanaan
Recana Pembangunan di Daerah Serta Dampaknya terhadap pembangunan Materi Hukum Tertulis Nasional," Disertasi, Bandung: Universitas Padjajaran, 1996.

Marbun, S.F, Hukum Administrasi Negara I, Yogyakarta: UII Press, 2012.

Menurut Hukum Publik dan Hukum Perdata, Bahan Kuliah pada Program Pendidikan lanjutan Ilmu Hukum Bidang Peradilan Tata Usaha Negara, Jakarta: Universitas Indonesia, 1992.

Mohammad Yuhdi, "Peran Diskresi dalam Penyelenggaraan Pemerintahan,"

LIKHITAPRAJNA Jurnal Ilmiah, Volume 15 No. 1.

Philipus M. Hadjon, et.al, Pengantar Hukum Administrasi Indonesia. Introduction to the Indonesian Administrative Law, Yogyakarta: Gadjah Mada University Press, 2011.

Sengketa Administrasi dalam Buku Bunga Rampai Hukum Tata Nagera dan Hukum Administrasi Negara, Yogyakarta : Jurusan HTN, Fakultas Hukum UII, 1987.

Soviah Hasanah, "Bentuk-Bentuk Maladministrasi," https://www.hukumonline.com/ klinik/a/bentuk-bentukmaladministrasilt58292617134da. 